The term "surplus killing" was first used by Kruuk to describe situations in which carnivores kill prey far in excess of that which can be consumed at one time. ${ }^{2}$ In this and many other reported instances of surplus killing, a predator is likely presented with an unusual abundance of vulnerable prey under circumstances that have been dubbed the "hen house syndrome". Although grebes were not the only abundant prey species present at these sites, they may have been more vulnerable than species such as Franklin's Gulls because of greater tenacity on the nest.

1. Ben- David, M., S.M. Pelios and V.C. Pellis. 1991. Feeding habits and predatory behaviour in the marbled polecat (Vormela perugusna syriaca): I. Killing methods in relation to prey size and prey behaviour. Behaviour 118:127-143

2. Kruuk, H. 1972. Surplus killing by carnivores. Journal of Zoology (London). 166:233-244

\title{
POCKET GOPHER/MOUSE ASSOCIATIONS ON THE MILK RIVER GRASSLANDS
}

JIM R. SALT, 464 Nelson Street, Victoria, BC V9A 6P4

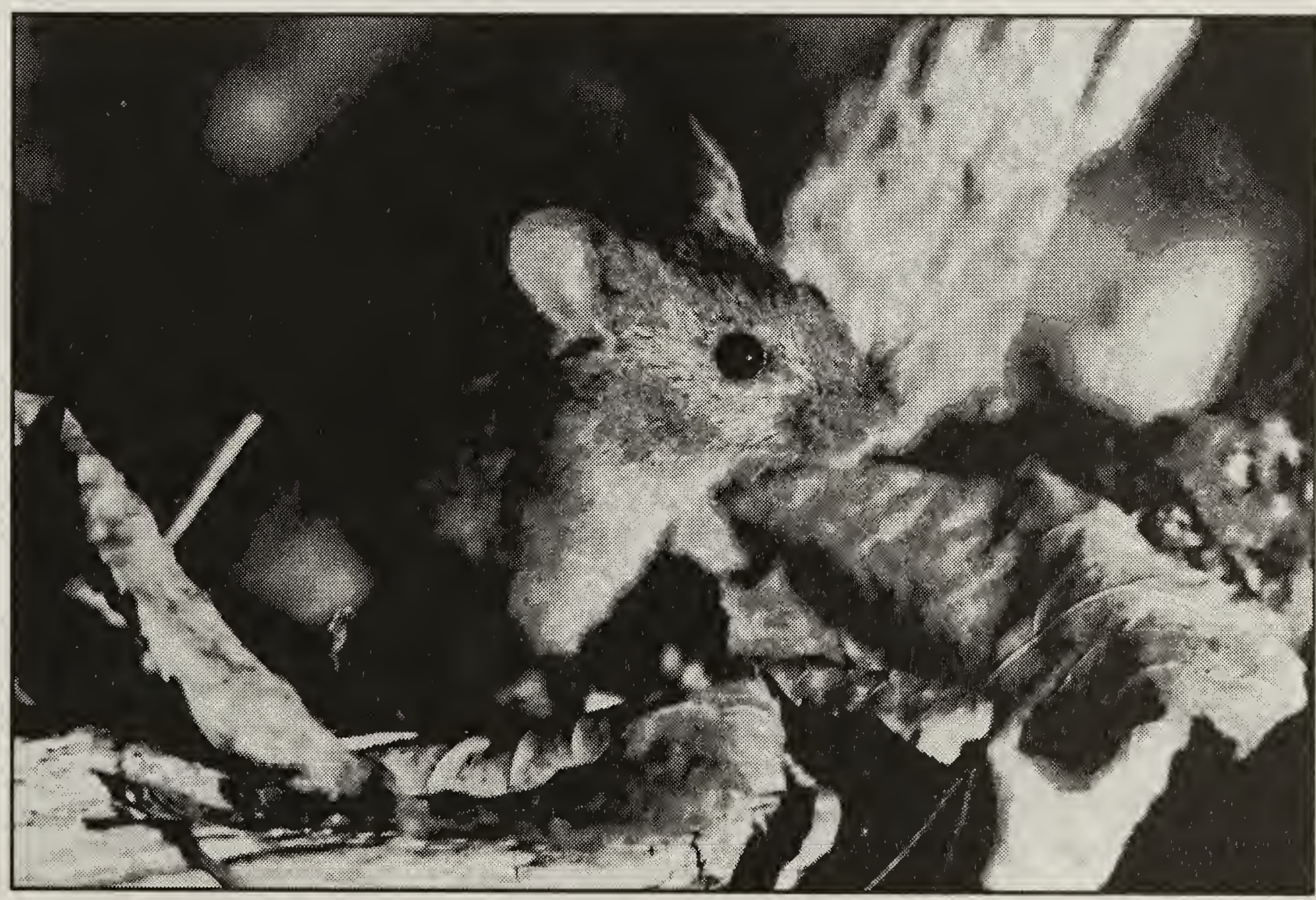


At the beginning of the 1990s, I undertook some small mammal studies on grasslands south of the Milk River, Alberta. The principal objective was to determine the status of the smallest mammals : mice, voles and shrews. The area of interest was a grassland mosaic of Spear Grass/Grama/Wheat Grass/ Fescue (Stipa/Bouteloua/Agropyron/ Festuca), located partly on what is now designated the Milk River Natural Area.

Previous studies in this habitat, using portable live traps and snap traps, had convinced me that these methods would be unproductive, and I adopted visual surveys supplemented by some secondary techniques. The area examined is an irregular polygon on the south rim of the Milk River valley, southeastward from the Pinhorn Grazing Reserve across the head of Kennedy Creek. The northwest corner of the study-area was at approximately $49^{\circ} 04^{\prime}$ $36^{\prime \prime} \mathrm{N}$ and $110^{\circ} 50^{\prime} 57^{\prime \prime} \mathrm{W}$ and the southeast corner was at approximately $49^{\circ} 00^{\prime} 48^{\prime \prime} \mathrm{N}$ and $110^{\circ} 43^{\prime} 59^{\prime \prime} \mathrm{W}$. In this polygon, about $32 \mathrm{~km}^{2}$ of grassland were examined and sampled. Three types of sample configuration were used: circular plots of $500 \mathrm{~m}^{2}$ and 1000 $\mathrm{m}^{2}$ each; long transects or walk-lines totaling approximately $18 \mathrm{~km}$, and approximately square grids of 1.1 to 2.2 $\mathrm{km}^{2}$. All mammalian sign on these was mapped. Some transects were completely barren and were abandoned or truncated. Supplementary trapping, track-dusting and baiting at obvious communities (dens and runways) helped to determine numbers and species of animals present, and extent of use.

The immediate aim of the project was to assess the numbers and distribution of voles and mice. Information on Northern Pocket Gophers (Thomomys talpoides) and ground squirrels (Spermophilus species) was examined only seven years later, in 1998. When communities of burrowing mammals were mapped, there was a clear correspondence between pocket gopher mound-groups and the dengroups of the mouse/vole communities. Other authors have commented on the fauna that use pocket gopher dens, which include insects and spiders, salamanders, toads, and some small mammals. ${ }^{3,4,6}$ Analysis of the Kennedy Creek data indicated that the mouse/ vole/gopher relationship was not a casual or occasional occurrence but was common on the study area, and might even be regarded as an ecological dependency.

Mouse/vole den sites were widely and very irregularly distributed over the study area; most of them (about 75\%) were in small clusters of six or fewer, without runways. Excepting three large communities, the density of mouse/vole den-groups varied from 0 per 100 metres (on 4 transects), to about 5 per $100 \mathrm{~m}$, averaging 1.8 den-groups per $100 \mathrm{~m}$ (for 13 transects). Intervals between groups varied from more than 1200 metres to only three metres, and distinguishing separate den-sites over short intervals was subject to interpretation. Trapping and headlighting indicated that two different species sometimes occupied dengroups only two to four metres apart. Pocket gopher sites were more numerous than were mouse/vole dengroups, varying from 1.2 mound-groups per $100 \mathrm{~m}$ to over 20 per $100 \mathrm{~m}$ (average 6.4 sites per $100 \mathrm{~m}$, on 13 transects).

Pocket gopher mounds were of several different ages. Fresh or recent ones had loose soil and a pocket gopher was still active at the site. Medium mounds showed no sign of new activity, but there was usually an occupant to replug dens opened by field workers. 1,2,5 A den left open might indicate that the 
occupant had left the site. Old mounds were compacted, partly re-vegetated, and had been abandoned for months or longer. The mice and voles were associated, not with the earth mounds, but with the feeding tunnels which extended many metres in several directions from the mounds, and sometimes led to other mound-groups.

Figure 1 indicates the distribution of mouse/vole den-groups and old pocket gopher mound-groups on a grid of four $1-\mathrm{km}$ transects at the west edge of the Milk River Natural Area, on typical terrain. The $X$ and $Y$ axes of the graph are the Universal Transverse Mercator map references found on topographic map sheet $72 \mathrm{E} / 2$. The grid lines represent 200 metre intervals.

Mice seemed to favour the sparse grasses and open ground of Spikemoss/
Everlasting (Selaginella/ Antennaria) communities, usually adjoining longer grass or shrub communities of snowberry (Symphoricarpos), juniper (Juniperus) and sage species (Artemisia). Three large den-groups were present in the study area. Each was 400 to $800 \mathrm{~m}^{2}$, and contained well-developed runways on a part of the area with 50 to 60 den openings. These major centres all were associated with old pocket gopher tunneling, and at least $70 \%$ of small densites were located at old pocket gopher earth-works. Some of the isolated mouse burrows, when excavated, proved to be associated with old pocket gopher feeding tunnels, even when situated more than $10 \mathrm{~m}$ from the nearest mounds. The only tunneling by the mice themselves, at most communities, consisted of small simple dens with short tunnels 2 to $4 \mathrm{~cm}$ diameter, without earthworks or runways. They descended

Fig. 1. Community-centres of voles and mice, and abandoned Northern Pocket Gopher (Thomomys talpoides) mound-groups mapped on a grid $1.2 \mathrm{~km}$ N/S by $1.6 \mathrm{~km}$ E/W. Data were collected along the four transect lines shown. Triangles are old pocket gopher mound-groups, circles are mouse-vole dengroups. Large ovals indicate major associations of the two.

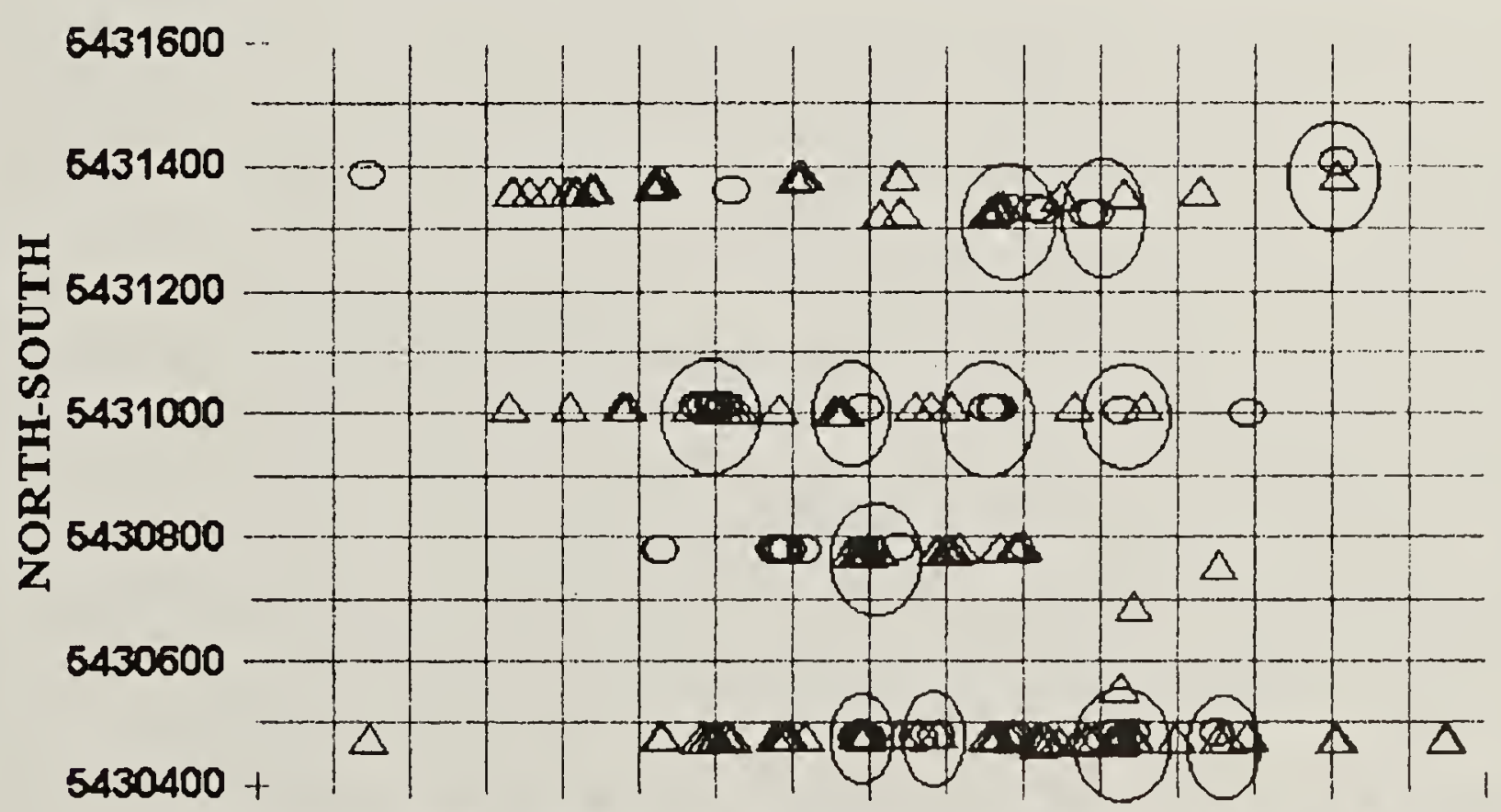

517600617800518000618200618400518600618800519000619200 EAST-WEST

UTM (12U) 
from 7 to $20 \mathrm{~cm}$ into abandoned pocket gopher feeding tunnels, 8 to $10 \mathrm{~cm}$ in diameter, which meandered away or led between mound-groups.

Trapping, baiting, and dusting at dens to record tracks, as well as nocturnal visual observation, proved that the larger mouse/gopher communities were inhabited by at least two, and as many as four, different small mammal species: Deer Mouse (Peromyscus maniculatus), Pocket Mouse (Perognathus fasciatus), Sagebrush Vole (Lagurus curtatus) and Meadow Vole (Microtus pennsylvanicus). Even in some smaller den-groups, Deer Mice were found with either Sagebrush Vole or Pocket Mouse. Meadow Vole was the least common species in these associations, and was found together with other species only in two large communities with extensive runways. Neither shrews (Sorexsp.) nor any of the "rare" mice (Harvest Mouse, Reithrodontomys megalotis or Grasshopper Mouse, Onychomys leucogaster) was detected by any of the study methods, although they had been collected previously by other workers in the same general area.

Dusting, baiting and trapping indicated that, even at large communities with obvious burrows and runways, only a few mice of any species were present. Some of the den-openings were no longer in use, and had been taken over by crickets or spiders with funnel webs or were plugged. The proportion of inactive to active dens, as indicated by dusting, varied at different communities, and seemed to be greater at larger communities where as many as $65 \%$ of the dens might be unoccupied.

Wershler noted an association between mice-voles and ground squirrel burrows in his study at the Antelope Creek Habitat Development Area, near Lake San Francisco, Alberta. ${ }^{7}$ The pocket gopher was absent at his sites, but voles and mice seemed to rely upon the tunnels of Richardson Ground Squirrels (Spermophilus richardsoni). The area was described by Wershler as more than $80 \%$ Spear Grass/Grama/ Wheat Grass, that is, communities superficially similar to the Milk River Grassland, but less diverse. At his first visit, his study area was much more heavily disturbed and grazed than the Milk River study area. Wershler summarized his methods and findings:

"Two straight-line $500 \mathrm{~m}$ transects were established in areas of high densities of Richardson's ground squirrels.... Numbers of recently active and old burrows were counted along a 5-meter transect strip, once a year in June for 5 consecutive years [1992 to 1996]....

Cricetid [mouse/vole] activity fluctuated greatly.... Centers of activity were in old ground squirrel burrow complexes .... The presence of Cricetids in upland grassland in the study area appeared to be largely dependent on the availability of old ground squirrel burrows."

In his report, Wershler referred to Richardson's Ground Squirrel as a "keystone species," in part because of the apparent dependency of the small mammal communities upon abandoned ground squirrel burrows.

My observations at Kennedy Creek, and those of Wershler at Antelope Creek, suggest that burrowing mammals, principally Northern Pocket Gopher and Richardson's Ground Squirrel, are of special significance to the small mammal ecology of the southern grasslands and thus to prairie ecology generally, particularly to mammalian predators and raptors. Major fluctuations in the burrowing mammal species could exert considerable influence, both directly upon voles and mice, and less directly upon other fauna. 
I am indebted to C. Wershler for making available his data on the Antelope Creek region, and for editorial comments on an early draft of this paper.

1. Engeman, Richard M., D.L. Campbell and J. Evans. 1993. A comparison of activity indicators for northern pocket gophers. Wildlife Society Bulletin. 21: 7073.

2. Engeman, R.M., D.L. Nolte and S.P. Bulkin. 1999. Optimization of the openhole method for assessing pocket gopher, Thomomys spp., activity. Canadian FieldNaturalist 113(2): 241-244.

3. Hansen, R.M. and R.S. Miller. 1959. Observations on the plural occupancy of pocket gopher burrow systems. Journal of Mammalogy 40(4): 577.

4. Kristensen, J. 1981. Tiger salamanders "rooming in" with northern pocket gophers. Alberta Naturalist 11: 171-172.
5. Matschke, G.H., R.T. Sterner, R.M. Engeman and J.M. O'Brien. 1994. Limitations of open-hole and plot occupancy indices in field efficacy studies with Townsend's pocket gophers. Society for Environmental Toxicology and Chemistry, Proceedings of the 15th Annual Meeting, Denver CO. 15: 245.

6. Vaughan, T.A. 1961. Vertebrates inhabiting pocket gopher burrows in Colorado. Journal of Mammalogy 42: 171-174.

7. Wershler, C. 2000. Wildlife surveys Antelope Creek Habitat Development Area, 1992-96. Report prepared by Sweetgrass Consultants Ltd. for Alberta Environment, Natural Resource Service, Lethbridge, $A B$.

"Dogwood was supposedly used to build the Trojan Horse. Cornus mas, or cornelian cherry, was valued by the Greeks for its exceptionally hard wood, used to make javelins and spears. John Parkinson said, 'The wood...is very hard, like unto horne and thereof it obtained the name' (from cornus, Latin for 'horn'). How

it became 'dogwood' has to do with its edible and medicinal qualities. The berries of the Cornus mas are said to be edible and were supposedly fed to Odysseus's men when they were changed into pigs by Circe. Cornus sanguinea, or English dogwood, was called by John Parkinson 'the Doggeberry tree because the berries are not fit to be eaten, or to be given to a dogge.' The Victorian garden writer John Loudon said that it was named because of a decoction of its leaves was used to wash fleas from dogs, and L. H. Bailey said in 1922 that it was used to bathe 'mangy dogs.' "

Diana Wells, 100 Flowers and How They Got Their Names p. 66 